\title{
Uşak Üniversitesi Banaz Meslek Yüksekokulu Öğrencilerinin İç Mekân Tasarımı Programını Tercih Etme Nedenleri
}

\author{
Abdurrahman Karamana ${ }^{\text {a }}$, Mehmet Nuri Yıldırımb ${ }^{b}$ İsmail Ertan Ertürk ${ }^{c}$ \\ aUşak Üniversitesi, Banaz Meslek Yüksekokulu, Uşak. \\ b,cKarabük Üniversitesi, Safranbolu Meslek Yüksekokulu, Karabük.
}

\begin{abstract}
$\ddot{O} z$
Meslek seçimi, kişilerin yaşamını etkileyen en önemli faktörlerden biridir. Meslek tercihi, genç kişiler için kolay bir süreç olmamaktadır. Bu çalışmanın amacı, İç Mekân Tasarımı mesleğini seçen öğrencilerin bu mesleği tercih etme nedenlerini tespit etmektir. Araştırmada Uşak Üniversitesi Banaz Meslek Yüksekokulu İç Mekân Tasarımı ön lisans programı öğrencilerinin katılımıyla anket yöntemi uygulanmış ve veriler üzerinden betimsel analizler yapılmıştır. Araştırma sonuçlarina göre genel olarak öğrencilerin kendi tercihleriyle; yeteneklerine uygun, kendilerini geliştirmede faydalı olacağın düşündükleri ve ilgi duydukları bir meslek olan İç Mekân Tasarımı programını seçtikleri ve bilinçli tercih yaptıkları sonucuna ulaşılmıştır.
\end{abstract}

Anahtar Kelimeler: Öğrenci, Meslek Seçimi, İç Mekân Tasarımı Eğitimi,

\section{The Reasons of Students' for Prefering the Interior Design Program in Uşak University Banaz Vocational School}

\begin{abstract}
The choice of profession is one of the most important factor influencing people's life. Choose of profession is not an easy process for the young people. The aim of this study to determine the reasons for choosing Interior Design Program among students. In this sense, a questionnaire was applied to the students of the Interior Design Program of the Banaz Vocational Higher School of the Usak University and all obtained data were evaluated for descriptive analysis. The results show that, students have chosen Interior Design Program in accordance with their preference and ability. However they think that Interior Design Program will be benefit in improving themselves.
\end{abstract}

Keywords: Student, Choice of Profession, Interior Design Education.

\section{GİRİ̧}

Meslek kişinin kimliğinin en önemli kaynağı olup, onun etraftan sayg1 görmesine, başkaları ile ilişki kurmasına, toplumda iyi bir yer edinmesine ve işe yaradığı duygusunu yaşamasına olanak veren bir etkinlik alanıdır (Sarıkaya ve Khorshid, 2009). Çağdaş bir toplumda; meslek seçimi bireyin çeşitli meslek gruplarından en iyi yapabileceğini düşündüğü faaliyetleri içeren ve kendisinin en üst düzeyde doyum sağlayacağına inandığı bir alana yönelmesidir Meslek seçimi kararı, insanın yaşamı boyunca vereceği en önemli kararlardan biri olup, meslek seçiminin bilinçli yapılması hem birey hem de ülke geleceği açısından büyük önem taşımaktadır. Çünkü birey verdiği kararla tüm yaşantısına şekil verecek bir süreci, yaşayacağı çevreyi ve ilişkide bulunacağı insanları da seçmiş olacaktır. Aynı zamanda meslek seçimi, kişinin aile gelirini, geçim tarzını, işini isteyerek yapıp yapmamasını, sorumluluk duygusunu ve mutlu olup olmamasını belirleyecek derecede önemlidir. Bu anlamda insanın yaşam biçiminin de seçimi olarak ifade edilebilecek meslek seçimi, 
insan hayatının en önemli dönüm noktalarından birisidir. $\mathrm{Bu}$ nedenle, bireyin mesleğine yönelik doğru bir karar alması, yaşamında mutlu ve başarılı olabilmesinde önemli rol oynamaktadır (Pekkaya ve Çolak 2013).

Bu araştırma, Uşak Üniversitesi Banaz Meslek Yüksekokulu Tasarım Bölümü İç Mekân Tasarımı programı I. ve II. sınıfta öğrenim gören öğrencilerin okudukları programı tercih etme nedenlerini belirlemek amacı ile yapılmıştır. İç mekân tasarımı programı çoğu üniversitelerde yeni açılmaktadır ve program mezunları; iç mimarlık, mimarlık, inşaat mühendisliği vb disiplinlerin ara kesit çalışanını oluşturmaktadır. Dolaysıyla bu araştırma sonuçları gençlerin meslek seçimine yönelik çalışmalara katkı sağlayacağı düşünülmektedir. Ayrıca literatürde meslek seçimi ile ilgili farklı alanlarda yapılan çalışmalar bulunmasına rağmen iç mekân tasarımı sektörüne yönelik yeterli düzeyde araştırma yapılmadığı ve literatür açısından bir eksiklik gösterdiği görülmektedir. Bu açıdan yapılan bu araştırmanın literatüre katkı sağlayacağı düşünülmektedir.

\section{LITERATÜR TARAMASI}

Türkiye'deki öğrencilerin herhangi bir üniversiteyi, fakülteyi veya bölümü tercih etmesini etkileyen birçok faktör bulunmaktadır. Öğrencilerin sosyo-ekonomik durumu, ebeveynlerinin öğrenim durumu, ebeveyn mesleği, eğitim gördüğü bölge ve il, tercih edilen mesleğin geleceğe dönük görünümü vb. gibi faktörler tercihler konusunda önemli oranda etkili olmaktadır (Erol vd., 2012: 5). Meslek yüksekokulları yapıları itibariyle, genellikle meslek lisesi mezunlarının devam ettiği okullar olmakla birlikte, mesleki ve teknik eğitim veren liseler haricindeki okullardan mezun olan öğrenciler tarafından da tercih edilmektedir. Liseye başlarken mesleki, genel ya da Anadolu Lisesi gibi seçenekler arasından birini seçmenin yanında, alan tercihi de yapan öğrencinin, daha önce gerçekleşmiş pek çok tercihi dolayısıyla meslek ve üniversite/bölüm seçimi etkilenmektedir (Sertel vd., 2017: 103).

Üniversite öğrencilerinin bölüm seçme nedenleri sıralamasına bakıldığında ilk sırayı bireysel ve sistemik etmenlerin aldığı, bunu sosyal etmenlerin izlediği ve en sonda da şans etmeninin yer aldığı görülmektedir. Öğrenciler, üniversite öğrenimi görme nedeni olarak en fazla "kendini geliştirme ve çağdaş bir insan olma" ve "meslek sahibi olma ve daha yüksek gelir elde etme" seçeneklerini belirtmişler, bu konudaki öğrenci yanıtları arasında, yaş, cinsiyet, lisans programı ve üniversitelere göre farklılık bulunamamıştır (Yolcu, 2011). Öğrencilerin meslek seçimini yaparken etkili olan faktörlerin öncelikle kariyer beklentisi, yüksek kazanç ve sorumluluk beklentisi, sosyal statü beklentisi, mesleki bilgi ve beceri, mesleki tecrübe, aile çevresi ve eğitim çevresi olduğu sonucuna ulaşılmıştır (Dinç, 2008). Öğrencilerin üniversite tercihlerini etkileyen en önemli faktörlerin akademik saygınlık, üniversitenin konumu ve bilgi kaynakları olduğu belirlenmiş, bu noktada üniversitelerdeki karar vericilerin öğretim elemanlarıyla öğrencilerin daha fazla etkileşim içinde oldukları, öğretim faaliyetlerinin kalitesinin arttırılması ve sürdürülmesi yönündeki önlemleri almaları akademik saygınlık açısından önemli görülmüştür (Akar, 2012). Üniversite öğrencileri üzerinde yapılan diğer bir araştırmada meslek seçimini etkileyen değerlere bakıldığında ilk üç 
sırayı; özel yaşam, yöneticilik ve güvenlik alırken; saygınlık en son sırada yer almıştır (Güllüce ve Kaygin, 2013).

Araştırmalarda, mesleki ve eğitsel kararlarda etkili olan faktörler ve yararlanılan kaynaklar (Hamamcı vd., 2013; Özyürek ve Kılıç-Atıcı, 2002;), lise öğrencilerinin alan seçimini etkileyen faktörler (Ulaş vd., 2017; Ulaş ve Yıldırım , 2015; Şengün, 2013; Hamamcı vd., 2013; Yolcu, 2011; Koç ve Sağlam, 2009; Yelken, 2008; Kıyak 2006), aile ve cinsiyet (Hamamcı ve Hamurlu, 2005; Uyguç, 2003; Akbayır, 2002), öğrencilerin sosyo-kültürel yapı (Alparslan ve Kılcıgil, 2005; Alper ve Özdemir, 2004; Altun, 2000), sosyo-kültürel-ekonomik ve kültürel faktörler (Güllüce, 2013; Taş, 2012; Ünal vd., 2008; Erdoğan vd., 2007; Aytekin, 2005), bölüm seçme nedenleri (Sertel vd., 2017; Gündoğan, 2016; Deniz, 2015; Dündar ve Özdemir, 2015; Çelik. ve Üzmez 2014; Akar, 2012; Korkut-Owen vd., 2012; Çitçi vd., 2011; Erkal vd., 2012; Erol vd., 2012; Kız̆̆ut ve Ergöl, 2011; Mizrak ve Şenel, 2011; Tataroğlu vd., 2011; Yücel vd., 2011; Dinç vd., 2007), meslek seçimini etkileyen faktörler (Ceylan vd., 2017; Özveren, 2017; Fuller ve Delorey, 2016; Suvacı ve Aydın, 2016; Sverko ve Babarovic, 2016; İnce ve Khorshid 2015; Cernicova ve Palea, 2014; Green vd., 2014; Baharlı vd., 2013; Erdem ve Kayran, 2013; Paulick vd., 2013; Pekkaya ve Çolak 2013; Saatc1, 2013; Erdinç ve Kahraman, 2012; Andsoy vd., 2012; Korkut-Owen vd., 2012; Sathapornvajana ve Watanapa, 2012; Watt vd., 2012; Demagalhaes vd., 2011; Y1lmaz vd., 2011; Baltacı ve Üngören, 2010; Hacıöemeroğlu vd., 2010; Sarıkaya ve Khorshid, 2009; Dinç, 2008; Özpancar vd., 2008; Şirin vd., 2008; Ünlü, 2008; Genç vd., 2007; Tunç vd.,2007; Tüfekçi ve Yıldız, 2007; Cullen vd., 2005; McCabe vd., 2005; Tamayose, 2004; Yanıkkerem vd., 2004; Özyürek vd., 2002; Deniz, 2001; Johnston vd., 1999) gibi değişkenler incelenmiştir.

Bu bağlamda model seçimini etkileyen bireysel, sosyal, ekonomik ve psikolojik faktörler boyutunda kavramsal çerçeve oluşturulmuştur.

Bireysel Özellikler: İlgi, yetenek, değer, amaç, beklenti, kişilik özellikleri, fiziksel özellikler, bireyin kendisi ve meslekler ile ilgili algılamaları, deneyimleri, mesleki olgunluk vb. bireysel özellikleri kapsamaktadır.

Sosyal Özellikler: Ailenin özellikleri, içinde yaşanılan kültürün mesleklere ve cinsiyete dayalı algılamaları, sosyal yapı, medya vb. özellikleri kapsamaktadır.

Ekonomik Özellikler: Ülkenin yönetim biçimi, ekonomik yapısı, yasalar, eğitim ve sınavla ilgili sistemler, iş bulma olanakları vb. özelliklerden oluşmaktadır.

Psikolojik Özellikler: Sağlık koşulları, doğal olaylar, beklenmedik karşılaşmalar vb. özellikleri ifade etmektedir (Korkut-Owen, 2008).

\section{MATERYAL VE YÖNTEM}

\subsection{Evren ve Örneklem}

Araştırmanın evrenini, 2017-2018 eğitim-öğretim yılında Uşak Üniversitesi, Banaz Meslek Yüksekokulunun İç Mekân Tasarımı Programına kayıtlı toplam 80 öğrenci oluşturmuştur. Örneklem seçimine gidilmemiş, araştırmaya katılmayı kabul eden tüm gönüllü öğrenciler araştırma kapsamına alınmıştır $(n=72)$. Çalışmaya katılım $\% 87.50$ 'dir. 


\subsection{Verilerin Toplanması ve Analizi}

Araştırmada, veri toplama aracı olarak anket tekniği kullanılmıştır. Anket soruları oluşturulurken daha önce yapılmış çalışmadan (Çelik ve Üzmez 2014; Suvacı ve Aydın 2016) yararlanılmıştır. Anket iki bölümden oluşmaktadır. İlk grupta öğrencilere ait sosyo-demografik özellikler sorulmuştur. Anketin ikinci bölümde ise öğrencilerin meslek seçimini etkileyen aktör ve faktörlere yönelik 25 adet 5'li likert ölçeğiyle (1. Hiç, 2. Az, 3. Orta, 4. Çok, 5. Pek çok) hazırlanmış ifade bulunmaktadır. Yasal izin alınarak, öğrencilerin anket çalışmasına katılımlarında gönüllülük esas alınmıştır. Veriler, Uşak Üniversitesi Banaz Meslek Yüksekokulu'nda, araştırmacılardan biri tarafından öğrencilerin kabul ettikleri uygun saatlerde, yüz yüze görüşme tekniği ile toplanmıştır. Araştırmadan elde edilen verilerin değerlendirilmesinde SPSS 20.0 paket programı kullanılmış, sonuçlar frekans (f) ve yüzde (\%) olarak verilmiştir. Meslek seçimini belirlemede etkili olan etmenleri belirlemek amacı ile belirlenen 25 soruluk anketin ikinci bölümüne güvenilirlik analizi yapılmış ve Cronbach Alfa katsayısı 0,720 $(0.70 \leq \alpha<1.00)$ olarak bulunmuştur. Bu bağlamda veri setinin iç tutarlılığının sağlandığı görülmektedir.

\section{BULGULAR VE TARTIŞMA}

\subsection{Sosyo-Demografik Bulgular}

$\mathrm{Bu}$ bölümde, araştırmaya katılan öğrencilerin sosyo-demografik özellikleri Tablo 1'deki gibi özetlenebilir.

Tablo 1. Katılımcıların Sosyo-Demografik Özellikleri

\begin{tabular}{|c|c|c|c|}
\hline & Değişkenler & Frekans & $\%$ \\
\hline \multirow{2}{*}{ Cinsiyet } & Kadın & 31 & 43,1 \\
\hline & Erkek & 41 & 56,9 \\
\hline \multirow{3}{*}{ Yaş aralı̆̆1 } & $17-19$ & 31 & 43,1 \\
\hline & $20-22$ & 35 & 48,6 \\
\hline & 23 ve üzeri & 6 & 8,3 \\
\hline \multirow{4}{*}{$\begin{array}{c}\text { Mezun olunan lise } \\
\text { türü }\end{array}$} & Fen/Anadolu Lisesi & 5 & 6,9 \\
\hline & Meslek Lisesi & 46 & 63,9 \\
\hline & Normal Lise & 9 & 12,5 \\
\hline & Diğer Liseler & 12 & 16,7 \\
\hline \multirow{5}{*}{$\begin{array}{l}\text { Ailenizin aylık gelir } \\
\text { durumu }\end{array}$} & Asgari ücret & 18 & 25 \\
\hline & $1301-2000 \mathrm{tl}$ & 29 & 40,3 \\
\hline & $2001-2700 \mathrm{tl}$ & 10 & 13,9 \\
\hline & $2701-3400 \mathrm{tl}$ & 3 & 4,2 \\
\hline & 3401 tl ve üzeri & 12 & 16,7 \\
\hline \multirow{5}{*}{ Anne eğitimi düzeyi } & Okur-yazar değil & 6 & 8,3 \\
\hline & İlköğretim & 49 & 68,1 \\
\hline & Lise & 14 & 19,4 \\
\hline & Üniversite & 3 & 4,2 \\
\hline & Üniversite & 8 & 11,1 \\
\hline
\end{tabular}


Tablo 1. Katılımcıların Sosyo-Demografik Özellikleri (Devamı)

\begin{tabular}{|c|c|c|c|}
\hline & Değişkenler & Frekans & $\%$ \\
\hline \multirow{4}{*}{ Baba eğitimi düzeyi } & Okur-yazar değil & 1 & 1,4 \\
\hline & İlköğretim & 46 & 63,9 \\
\hline & Lise & 17 & 23,6 \\
\hline & Üniversite & 8 & 11,1 \\
\hline \multirow{5}{*}{ Anne mesleği } & İşçi & 9 & 12,5 \\
\hline & Memur & 1 & 1,4 \\
\hline & Emekli & 3 & 4,2 \\
\hline & Ev hanımı & 52 & 72,2 \\
\hline & Serbest & 7 & 9,7 \\
\hline \multirow{4}{*}{ Baba mesleği } & İşçi & 22 & 30,6 \\
\hline & Memur & 7 & 9,7 \\
\hline & Emekli & 18 & 25 \\
\hline & Serbest & 25 & 34,7 \\
\hline \multirow{4}{*}{ Sınava giriş sayısı } & 1. Giriş & 49 & 68,1 \\
\hline & 2. Giriş & 12 & 16,7 \\
\hline & 3. Giriş & 9 & 12,5 \\
\hline & $\begin{array}{l}4 \text { ve daha fazla } \\
\text { sayıda }\end{array}$ & 2 & 2,8 \\
\hline \multirow{4}{*}{ Tercih s1rası } & 1-6 tercih & 64 & 88,9 \\
\hline & 7-12 tercih & 4 & 5,6 \\
\hline & 13-18 tercih & 3 & 4,2 \\
\hline & 19-24 tercih & 1 & 1,4 \\
\hline
\end{tabular}

Tablo 1'de görüldüğü gibi, katılımcıların \% 56,9'u (41 kişi) erkek, \%43,1 (31 kişi) bayan öğrencilerden oluşmaktadır. Öğrencilerin yaş aralıkları incelendiğinde; 1719 yaş arası \%43,1'i (31 kişi), 20-22 yaş arası \%48,6's1 (35 kişi), 23 ve üzeri ise \%8,3'ü (6 kişi) bulunmaktadır. Mezun olunan lise türüne göre sınıflandırıldığında; meslek lisesi grubun \%63,9'u (46 kişi) ağırlı̆̆ı göze çarpmaktadır. Aile gelir düzeyleri incelendiğinde ise; \%40,3'ü (29 kişi) 1301-2000 TL, \%25'i (18 kişi) asgari ücret, \%16,7'si (12 kişi) 3401 TL ve üzeri, \%13,9'u (10 kişi) 2001-2700 TL, \%4,2'si (3 kişi) 2701-3400 TL gelire sahip olduğu belirlenmiştir. Ailenin eğitim düzeyi çocukların meslek seçimlerine destek olabilmeleri açısından önemlidir. Öğrencilerin \%68,1'inin (49 kişi) annesi, \%63,9'unun (43 kişi) babası ilköğretim mezunudur. Anne mesleğine göre öğrenci dağılımına bakıldığında ise annesi çalışmayan/ev hanımı olan öğrenci oranı \%72,2'dir (52 kişi). Baba mesleği; serbest \%34,7, işçi \%30,6 ve emekli \%25 olan öğrencilerin oranları birbirine yakındır. Öğrencilerin \%68,1'i (49 kişi) programı ilk girişte kazandığını, \%88,9'u (64 kişi) programın 1-6 tercih sırasında yer aldığını belirtmiştir. Buradan araştırmaya katılan öğrencilerin iç mekân tasarımı programını öncelikli olarak tercih ettikleri düşünülebilir. 


\subsection{Meslek Seçimine Yönelik Bulgular}

Ankete katılan öğrencilerin meslek seçimini etkileyen faktörlere yönelik tutumları dört başlık altında ele alınmıştır. Katılımcıların meslek seçimini etkileyen aktörlere yönelik tutumları Tablo 2'deki gibidir.

Tablo 2. Katılımcıların Meslek Seçiminde Etkili Olan Aktörlere Yönelik Tutumları

\begin{tabular}{lcc}
\hline \multicolumn{1}{c}{ Önermeler } & Frekans & \% \\
\hline Bu mesleği seçmem tamamen benim tercihimdi & 26 & 36,1 \\
\hline Bu mesleği ailem istediği için & 5 & 6,9 \\
\hline İş olană̆1 yüksek oluğu için & 18 & 25 \\
\hline İdeallerimi gerçekleştirmek için & 17 & 23,7 \\
\hline Bu mesleği arkadaşlarımin tavsiyesiyle seçtim & 6 & 8,3 \\
\hline
\end{tabular}

Araştırmaya katılan öğrencilerin büyük bir kısmı \%36,1'inin (26 kişi) bu mesleği seçmelerinin tamamen kendi tercihi olduğu görülmektedir. Bunu sirasıyla \%25'i (18 kişi) iş olanağ 1 yüksek olduğu için, \%23,7'si (17 kişi), ideallerini gerçekleştirmek için, \%8,3'ü (6 kişi) arkadaşlarının tavsiyesi sonucunda iç mekân tasarımı programını tercih ettiklerini ifade etmişlerdir. Meslek seçiminde ailenin önemli bir aktör olduğu bilinmekle birlikte, katılımcıların \%6,9'unun (5 kişi) ailesinin yönlendirmesi veya isteği işe bu mesleği seçtikleri görülmektedir. Araştırmaya katılan öğrencilerin 93,1'i (67 kişi) kayıtlı olduğu iç mekân tasarımı programını isteyerek tercih ettikleri, \%55,6'sı (40 kişi) programdan çok memnun olduklarını ifade etmişlerdir. Öğrencilerin \%36,1'i (26 kişi) mesleği sevdiği için, \%25'i (18 kişi) iş olanağ1 yüksek olduğu için, \%23,7'si (17 kişi), ideallerini gerçekleştirmek için, \%8,3’ü (6 kişi) yanıt vermediği, \%6,9'u (5 kişi) ailesi istediği için iç mekân tasarımı programını tercih ettikleri belirlenmiştir.

Katılımcıların meslek seçimini etkileyen aktörlere yönelik tutumları dört başlık altında ele alınmıştır. Tablo 3 katılımcıların meslek seçimini etkileyen faktörlere ilişkin olarak elde edilmiş sonuçları göstermektedir. 
Tablo 3. Katılımcıların Meslek Seçimini Etkileyen Faktörlere Yönelik Tutumları

\begin{tabular}{|c|c|c|c|c|c|c|c|c|}
\hline \multirow{2}{*}{$\begin{array}{c}\text { Temel } \\
\text { Faktörler }\end{array}$} & \multirow[t]{2}{*}{ Önermeler } & K1 & $\mathrm{K} 2$ & K3 & K4 & K5 & $\frac{6}{6}$ & SS \\
\hline & & $\%$ & $\%$ & $\%$ & $\%$ & $\%$ & $\%$ & $\%$ \\
\hline \multirow{3}{*}{ (⿹勹巳 } & Bu mesleğe ilgim vardır. & 1,4 & 5,6 & 9,7 & 40,3 & 43 & 4,18 & ,92 \\
\hline & $\begin{array}{l}\text { Bu mesleğin beni mutlu edeceğini } \\
\text { düşünüyorum. }\end{array}$ & 1,4 & 4,2 & 11,1 & 38,9 & 44,4 & 4,28 & 90 \\
\hline & $\begin{array}{l}\text { Kendi istek ve ideallerimi } \\
\text { gerçekleştirmek için tercih ettim. }\end{array}$ & 0,0 & 1,4 & 5,6 & 38,9 & 54,2 & 4,45 & 67 \\
\hline \multirow{10}{*}{ 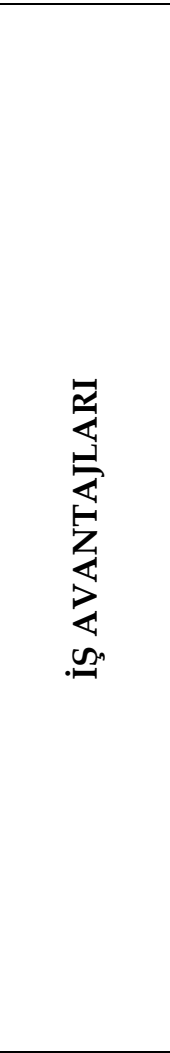 } & $\begin{array}{l}\text { Mezun olduğumda kolaylıkla iş } \\
\text { bulabileceğimi düşünüyorum. }\end{array}$ & 1,4 & 5,6 & 25 & 31,9 & 36,1 & 3,95 & ,98 \\
\hline & $\begin{array}{l}\text { Sektörün nitelikli işgücü ihtiyacı } \\
\text { tercihimde etkili oldu. }\end{array}$ & 1,4 & 9,7 & 22,2 & 45,8 & 20,8 & 3,75 & ,95 \\
\hline & $\begin{array}{l}\text { Kazancı yüksek bir meslek olduğunu } \\
\text { düşünüyorum. }\end{array}$ & 4,2 & 5,6 & 31,9 & 33,3 & 25 & 3,69 & 1,04 \\
\hline & $\begin{array}{l}\text { Bu meslekte kariyer imkânlarının } \\
\text { olduğunu düşünüyorum. }\end{array}$ & 2,8 & 2,8 & 20,8 & 37,5 & 36,2 & 4,01 & ,97 \\
\hline & $\begin{array}{l}\text { Gelecekte başka mesleklere girmemi } \\
\text { kolaylaştıracak bilgi ve beceri } \\
\text { kazandıracağın düşünüyorum. }\end{array}$ & 5,6 & 4,2 & 26,4 & 31,9 & 31,9 & 3,81 & 1,11 \\
\hline & $\begin{array}{l}\text { Kendimi geliştirmeme olanak } \\
\text { tanıyacak bir meslek olduğu için } \\
\text { seçtim }\end{array}$ & 0,0 & 1,4 & 11,1 & 31,9 & 55,6 & 4,42 & ,75 \\
\hline & $\begin{array}{l}\text { Toplumda sayginlığı olan bir meslek } \\
\text { olduğunu düşünüyorum. }\end{array}$ & 1,4 & 1,4 & 27,8 & 37,5 & 31,9 & 3,97 & 89 \\
\hline & $\begin{array}{l}\text { Bu mesleğin esnek çalışma koşulları } \\
\text { tercihimde etkili oldu. }\end{array}$ & 0,0 & 1,4 & 29,2 & 37,5 & 31,9 & 4,00 & 82 \\
\hline & $\begin{array}{l}\text { Güven esasına dayalı bir meslek } \\
\text { olmasından dolayı tercih ettim. }\end{array}$ & 0,0 & 2,8 & 22,2 & 50,0 & 25 & 3,97 & ,77 \\
\hline & $\begin{array}{l}\text { Bağımsız çalışmaya uygun bir meslek } \\
\text { olduğunu düşünüyorum. }\end{array}$ & 0,0 & 4,2 & 26,4 & 43,1 & 26,4 & 3,92 & 84 \\
\hline \multirow{3}{*}{ 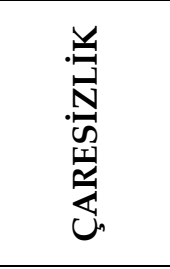 } & $\begin{array}{l}\text { Bir üniversite bitirmiş olmak için } \\
\text { tercih ettim. }\end{array}$ & 41,7 & 16,7 & 19,4 & 13,9 & 8,3 & 2,31 & 1,36 \\
\hline & Bir mesleğim olması için tercih ettim. & 16,7 & 15,3 & 9,7 & 37,5 & 20,8 & 3,31 & 1,40 \\
\hline & $\begin{array}{l}\text { Puanım bu programa yettiği için } \\
\text { tercih ettim. }\end{array}$ & 27,8 & 20,8 & 18,1 & 22,2 & 11,1 & 2,68 & 1,38 \\
\hline \multirow{4}{*}{ 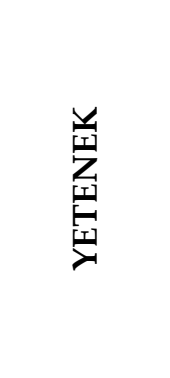 } & $\begin{array}{l}\text { İnsanlarla iyi iletişim kurabildiğim } \\
\text { için seçtim. }\end{array}$ & 11,1 & 8,3 & 27,8 & 40,3 & 12,5 & 3,35 & 1,15 \\
\hline & $\begin{array}{l}\text { İnsanlara hizmet etmeyi sevdiğim için } \\
\text { seçtim. }\end{array}$ & 2,8 & 6,9 & 26,4 & 45,8 & 18,1 & 3,69 & ,94 \\
\hline & $\begin{array}{l}\text { İkna yeteneğimin iyi olduğunu } \\
\text { düşündüğüm için seçtim. }\end{array}$ & 8,3 & 20,8 & 45,8 & 22,2 & 2,8 & 2,91 & 1,39 \\
\hline & $\begin{array}{l}\text { Planlama konusunda iyi olduğum } \\
\text { için seçtim. }\end{array}$ & 1,4 & 8,3 & 23,6 & 41,7 & 25 & 3,81 & 96 \\
\hline
\end{tabular}

Not: (K1: Hiç, K2: Az, K3: Orta, K4: Çok, K5: Pek çok)

Tablo 3 yorumlanırken orta, çok ve pek çok seçenekleri olumlu; hiç ve az seçenekleri olumsuz olarak değerlendirilmiştir. Katılımcıların seçimini etkileyen temel 
faktörlerden mesleğe ilgi başlıkta en yüksek aritmetik ortalama "Kendi istek ve ideallerimi gerçekleştirmek için tercih ettim" $(\bar{X}=4,45)$ ifadesinde gerçekleşirken, en düşük aritmetik ortalama "Bu mesleğe ilgim vardır" $(\bar{X}=4,18)$ ifadesinde gerçekleşmiştir. Katılımcıların \%93'ü seçmiş oldukları mesleğe ilgi duymaktadır. Katılımcılar bir yandan bu mesleğin hayallerindeki/ideallerindeki meslek olduğunu ifade ederken, öte yandan bu mesleği yapmanın kendilerini mutlu edeceklerini ifade etmişlerdir. $\mathrm{O}$ halde, bu düşüncenin nedenini iş avantajları ve yetenek faktörlerinde aramak gerekecektir. Katılımcıların seçimini etkileyen temel faktörlerden iş avantajları başlıkta en yüksek aritmetik ortalama "Kendimi geliştirmeme olanak tanıyacak bir meslek olduğu için seçtim" ( $\bar{X}=4,42)$ ifadesinde gerçekleşirken, en düşük aritmetik ortalama "Kazanc1 yüksek bir meslek olduğunu düşünüyorum" $(\bar{\chi}=4,18)$ ifadesinde gerçekleşmiştir. Katılımcıların \%88,8'i sektörde nitelikli işgücü ihtiyacı olduğunun farkındadır ve bu nedenle neredeyse tamamına yakını \%93'ü okuldan mezun olduğunda kolay iş bulabileceğini düşünmektedir.

Katılımcıların \%90,2'si bu mesleğin kazancının yüksek olduğunu; \%94,5'i kariyer yapmaya imkân tanıdığını; \%90,2'si bu mesleğin gelecekte başka mesleklere girmelerini kolaylaştıracak bilgi ve beceriyi kazandıracağını; \%98,6'sı bu mesleklerin kendilerini geliştirmede faydalı olacağını, \%97,2'si toplumda saygınlığı olan bir meslek olduğunu; \%98,6'sı esnek çalışma koşullara sahip bir meslek olduğunu; \%97,2'si güven esasına dayalı meslek olduğunu; \%95,8'i ise bağımsız çalışmaya uygun meslek olduğunu düşünmektedir. İş avantajlarıyla ilgili sonuçlara bakıldığında öğrencilerin büyük çoğunluğun mesleklerin iş avantajına sahip olduğunu düşündüğü söylenebilir. Katılımcıların seçimini etkileyen temel faktörlerden çaresizlik başlıkta en yüksek aritmetik ortalama "Bir mesleğim olması için tercih ettim" ( $\bar{X}=3,31)$ ifadesinde gerçekleşirken, en düşük aritmetik ortalama "Bir üniversite bitirmiş olmak için tercih ettim" ( $\bar{x}=2,31)$ ifadesinde gerçekleşmiştir.

Çaresizlikle ilgili olarak sorulan sorulara bakıldığında, katılımcıları \%41,6'sı bir üniversite bitirmiş olmak için, \%68'i bir mesleği olması için, \%51,3'ü ise sınav puanının bu programa yettiği için tercih ettiklerini belirtmiştir. Katılımcıların seçimini etkileyen temel faktörlerden yetenek başlıkta en yüksek aritmetik ortalama "Planlama konusunda iyi olduğum için seçtim" ( $\bar{x}=3,81)$ ifadesinde gerçekleşirken, en düşük aritmetik ortalama "İkna yeteneğimin iyi olduğunu düşündüğüm için seçtim" ( $\bar{X}=2,91)$ ifadesinde gerçekleşmiştir. Mesleklerin yeterliliklerine yer verilen yetenek kategorisinde faktörlerin etki düzeyine bakıldığında \%50'nin altında bir sonuç yoktur. $\mathrm{Bu}$ ise öğrencilerin en az yarısının aslında meslekler için gerekli olan yeteneklere sahip olduklarını düşündüğünü göstermektedir. İnsanlarla iyi bir iletişim kurabilme yeteneği iç mekân tasarımı mesleği için sahip olunması gereken önemli bir yetenektir ve öğrencilerin \%80,6'sı bu yeteneğe sahip olduğunu düşünmektedir. Aynı şekilde katılımclar insanlara hizmet etmeyi sevdiklerini (\%90,3), ikna yeteneğine sahip olduklarını $(\% 63,9)$, planlama konusunda iyi olduklarını düşündüklerini $(\% 63,8)$ belirtmişlerdir. Tüm bu yetenekler bu meslek için olumlu sayılan yeteneklerdir.

Meslek yüksekokulu öğrencilerinin eğitim aldıkları programı tercih etme nedenlerini ölçmek üzere 20 Likert tipi anket sorusu; faktör analizi ile katılımcıların 
verdikleri cevaplara göre konunun kaç faktörden oluştuğu ve hangi soruların hangi faktörü oluşturduğu incelenmektedir. Öncelikle verilerin faktör analizi yapmaya uygun olduğunun belirlenmesi amaciyla örnekleme yeterliliği istatistiği (KMO >0,50) ve Barlett küresellik testi $(\mathrm{p}<0,05)$ sonuçları bulunmuştur (Sipahi vd., 2010:79 ; Anafarta, 2014, Şahin-Ören, 2017). Buna göre Kaiser-Meyer-Olkin (KMO) değeri 0, 75 ve Barlett test sonucunda $\mathrm{p}$ değeri, 000 olarak test edilmiştir. Sonra ki aşamada "Döndürmeye tabi tutulmuş faktör matrisi (rotated component matrix)"nde bazı sorularda birbirine çok yakın faktör yüklerinin olduğu tespit edilmiştir. Tablo 4 katılımcıların meslek seçimini etkileyen faktörlere ilişkin döndürülmüş yüklemeler matrisi (çıartma yöntemi: temel bileşenler analizi döndürme yöntemi: varimax) olarak elde edilmiş faktör yükü sonuçları göstermektedir.

Tablo 4. Döndürülmüş Yüklemeler Matrisi (Çıkartma Yöntemi: Temel Bileşenler Analizi. Döndürme Yöntemi: Varimax )

\begin{tabular}{|c|c|c|}
\hline $\begin{array}{c}\text { Temel } \\
\text { Faktörler }\end{array}$ & Önermeler & $\begin{array}{l}\text { Faktör } \\
\text { Yükü }\end{array}$ \\
\hline \multirow{3}{*}{ త్] } & Bu mesleğe ilgim vardır. & 0,610 \\
\hline & Bu mesleğin beni mutlu edeceğini düşünüyorum. & 0,760 \\
\hline & Kendi istek ve ideallerimi gerçekleştirmek için tercih ettim. & 0,802 \\
\hline \multirow{10}{*}{ 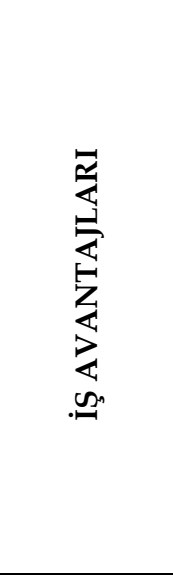 } & Mezun olduğumda kolaylıkla iş bulabileceğimi düşünüyorum. & 0,554 \\
\hline & Sektörün nitelikli işgücü ihtiyacı tercihimde etkili oldu. & 0,585 \\
\hline & Kazancı yüksek bir meslek olduğunu düşünüyorum. & 0,718 \\
\hline & Bu meslekte kariyer imkânlarının olduğunu düşünüyorum. & 0,827 \\
\hline & $\begin{array}{l}\text { Gelecekte başka mesleklere girmemi kolaylaştıracak bilgi ve } \\
\text { beceri kazandıracağın düşünüyorum. }\end{array}$ & 0,632 \\
\hline & $\begin{array}{l}\text { Kendimi geliştirmeme olanak tanıyacak bir meslek olduğu için } \\
\text { seçtim }\end{array}$ & 0,811 \\
\hline & Toplumda saygınlığı olan bir meslek olduğunu düşünüyorum. & 0,596 \\
\hline & Bu mesleğin esnek çalışma koşulları tercihimde etkili oldu. & 0,684 \\
\hline & Güven esasına dayalı bir meslek olmasından dolayı tercih ettim. & 0,690 \\
\hline & Bağımsız çalışmaya uygun bir meslek olduğunu düşünüyorum. & 0,611 \\
\hline \multirow{3}{*}{ 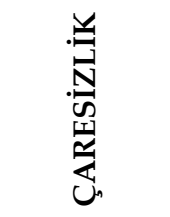 } & Bir üniversite bitirmiş olmak için tercih ettim. & 0,765 \\
\hline & Bir mesleğim olması için tercih ettim. & 0,591 \\
\hline & Puanım bu programa yettiği için tercih ettim. & 0,716 \\
\hline \multirow{4}{*}{ 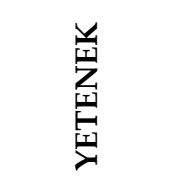 } & İnsanlarla iyi iletişim kurabildiğim için seçtim. & 0,459 \\
\hline & İnsanlara hizmet etmeyi sevdiğim için seçtim. & 0,685 \\
\hline & İkna yeteneğimin iyi olduğunu düşündüğüm için seçtim. & 0,439 \\
\hline & Planlama konusunda iyi olduğum için seçtim. & 0,500 \\
\hline
\end{tabular}

Tablo 4'e göre birinci faktör 3, ikinci faktör 10, üçüncü faktör 3 ve dördüncü faktör ise 4 soruyu içermektedir. Birinci faktörü oluşturan soruların faktör yükleri 0,610 ile 0,802 arasında, ikinci faktörü oluşturan soruların faktör yükleri 0,554 ile 0,827 arasında, üçüncü faktörü oluşturan soruların faktör yükleri 0,591 ile 0,765 arasında ve 
dördüncü faktörü oluşturan soruların faktör yükleri ise 0,439 ile 0,685 arasında değişmektedir.

\section{SONUÇLAR VE ÖNERİLER}

Bu çalışma, Uşak Üniversitesi Banaz Meslek Yüksekokulu'nda I.ve II. sınıf İç Mekân Tasarımı programında öğrenim gören 72 öğrenciye uygulanan anket çalışması neticesinde hazırlanmıştır. Katılımcılara ilk aşamada demografik bilgiler, ikinci aşamada ise araştırmaya katılan öğrencilerin bu mesleği tercih etme nedenlerini ve bilinç düzeyini belirlemeyi amaçlanmıştır. Tüm test sonuçları SPSS 20.0 istatistiksel analiz programlarında değerlendirilmiş, elde edilen bulgular frekans analizi uygulanarak değerlendirilmiştir. Araştırmadan elde edilen sonuçlar şöyle özetlenebilir.

Araştırmaya katılan öğrencilerin \%56,9'unu erkek, \%43,1'inin kız öğrencilerden oluştuğu, öğrencilerin yaş yoğunluğu olarak \%48,6'sının 20-22 yaş ve \%43,1'inin 17-19 yaş aralığında olduğu, öğrencilerin \%63,9'unun Meslek Lisesi olduğu belirlenmiştir. Öğrencilerin \%68,1'inin annesi, \%63,9'unun babası ilköğretim mezunu olduğu, öğrencilerin \%65,3'ünün orta gelirli ailelerden geldiği sonucuna ulaşılmıştır. Öğrencilerin \%68,1'inin bölümü ilk girişte kazandığı, öğrencilerin $\% 88,9$ 'unun bölümü 1-6 tercih ettiği belirlenmiştir.

Ailenin eğitim düzeyi çocukların meslek seçimlerine destek olabilmeleri açısından önemlidir. Öğrencilerin \%68,1'inin (49 kişi) annesi, \%63,9'unun (43 kişi) babası ilköğretim mezunudur. Katılımcıların büyük bir çoğunluğunun anne ve babalarının ilköğretim mezunu olması, birçok çalışma bulgularıyla paralellik göstermektedir. (Eşer ve ark. 2008; Ünlü ve ark. 2008; Koç ve Sağlam 2009; Yücel ve ark. 2011; Andsoy ve ark. 2012; Deniz 2015; Suvacı ve Aydın 2016). Lise öğrencilerinin kendi ilgi, yetenek, değer, kişilik özellikleri ve sosyo-ekonomik düzeylerine uygun alan ve meslek seçimlerinde aile desteği önemli olmaktadır (Ulaş ve Yıldırım, 2015). Nijerya'da yapılan bir çalışmada anne-babanın eğitim düzeyinin ve çalışma durumunun bireyin yaşam koşullarını ve yaşadığı ortamın kültür seviyesini belirlediği, bundan dolayı ebeveynlerin eğitim düzeyinin, bireylerin meslek tercihlerini etkileyen önemli bir faktör olduğu ortaya konulmuştur (Udoh ve Sanni, 2012). Ailenin eğitim düzeyinin en azından lise düzeyinde olması öğrenciye daha fazla yardımcı olabilmesi açısından önemlidir. Anne meleğine göre öğrenci dağılımına bakıldığında ise annesi çalışmayan/ev hanımı olan öğrenci oranı \%72,2'dir (52 kişi). Baba mesleği; serbest \%34,7, işçi \%30,6 ve emekli \%25 olan öğrencilerin oranları birbirine yakındır. Öğrencilerin \%68,1'i (49 kişi) programı ilk girişte kazandığını, \%88,9'u (64 kişi) programın 1-6 tercih sırasında yer aldığını belirtmiştir. Buradan araştırmaya katılan öğrencilerin yarısından fazlasının iç mekân tasarımı programını öncelikli olarak tercih ettikleri anlaşılmaktadır. Bu bulgu, literatür bulguları ile benzerlik göstermektedir (Dinç ve ark. 2007; Ünlü ve ark. 2008; Özpancar ve ark. 2008; Şirin ve ark.2008; Tunç ve ark. 2010; Andsoy ve ark. 2012; İnce ve Khorshid 2015; Suvacı ve Aydın 2016; Karaman ve ark.2017).

Araştırmaya katılan öğrencilerin 93,1'i (67 kişi) kayıtlı olduğu iç mekân tasarımı programını isteyerek tercih ettikleri, \%55,6'sı (40 kişi) programdan çok memnun 
olduklarını ifade etmişlerdir. Öğrencilerin \%36,1'i (26 kişi) mesleği sevdiği için, \%25'i (18 kişi) iş olanağ1 yüksek olduğu için, \%23,7'si (17 kişi), ideallerini gerçekleştirmek için, \%8,3'nün (6 kişi) yanıt vermediği, \%6,9'u (5 kişi) ise ailesi istediği için iç mekân tasarımı programını tercih ettikleri belirlenmiştir. Literatür incelendiğinde araştırmaların daha çok eğitim fakültelerine bağlı bölümler ve hemşirelik bölümlerinde yapıldığ1 görülmektedir. Erdoğan ve ark. (2005) eğitim fakültesi öğrencileri ile yapmış oldukları araştırmada öğrencilerin nerdeyse yarısına yakınının öğretmenliğin ideallerindeki meslek olduğunu belirttikleri bulunmuştur. Özsoy ve ark. (2010) tarafından gerçekleştirilen benzer bir çalışmanın bulgularına göre; öğretmen adaylarının yarısından fazlası bölümü seçme nedenini puanlarının bu bölüme yetmesi olarak göstermektedir. Benzer olarak Hacıömeroğlu ve Taşkın (2010)'ın fen bilgisi öğretmen adaylarıyla yaptıkları çalışmada da öğrencilerin çoğunun, aldıkları puanlar sebebiyle bu mesleği tercih ettikleri görülmüştür. Tataroğlu ve ark. (2011) tarafından matematik öğretmenliği bölümünü kazanan öğretmen adayları ile yapılan çalışmada öğretmen adaylarının nerdeyse yarısının bu bölümü duydukları ilgi nedeniyle, yaklaşı beşte birinin puanları diğer tercihlerine yetmediği için seçtikleri sonucuna ulaşılmıştır. Hemşirelik bölümünde okuyan öğrencilerle Tunç ve ark. (2007) tarafından yapılan bir araştırmada öğrencilerin üçte birinin sosyal bir etmen olan yakın çevre ve aileleri tarafından mesleğe yönlendirildikleri; Kız̆̆ut ve Ergül'ün (2011) gerçekleştirdikleri benzer bir çalışmada öğrencilerin ağırlıklı olarak alanı iş bulma kolaylığı nedeniyle bu alanı seçtiklerini tespit etmişlerdir. Andsoy ve ark. (2012) tarafından yapılan bir araştırmada ise öğrencilerin \%64'ü hemşireliğin ideallerindeki meslek olduğunu belirtmişlerdir.

Araştırmaya katılan katılımcıların \%93'ü seçmiş oldukları mesleğe ilgi duyduğunu ifade etmişlerdir. Katılımcılar mesleğin hem hayallerindeki/ideallerindeki meslek olduğunu, hem de mesleği yapmanın kendilerini mutlu edeceklerini ifade etmişlerdir. Çelik ve Üzmez (2014) tarafından yapılan çalışmada çağrı hizmetleri programı öğrencilerin yarısından fazlası \%79'u mesleğe ilgi duyduklarını belirtmişlerdir. Suvacı ve Aydın (2016) çalışmasında ise katılımcıların yalnızca \%39'u seçmiş oldukları mesleğe ilgi duydukları belirtmişlerdir.

Katılımcların \%90,2'si bu mesleğin kazancının yüksek olduğunu; \%94,5'i kariyer yapmaya imkân tanıdığını; \%90,2'si bu mesleğin gelecekte başka mesleklere girmelerini kolaylaştıracak bilgi ve beceriyi kazandıracağını; \%98,6'sı bu mesleklerin kendilerini geliştirmede faydalı olacağını, \%97,2'si toplumda saygınlığı olan bir meslek olduğunu; \%98,6'sı esnek çalışma koşullara sahip bir meslek olduğunu; \%97,2'si güven esasına dayalı meslek olduğunu; \%95,8'i ise bağımsız çalışmaya uygun meslek olduğunu düşünmektedir. İş avantajlarıyla ilgili sonuçlara bakıldığında öğrencilerin büyük çoğunluğun mesleklerin iş avantajına sahip bir meslek olmasından dolayı tercih ettikleri söylenebilir. Çelik ve Üzmez (2014) tarafından yapılan çalışmada çağrı hizmetleri programı öğrencilerin \%96'sı mezun olunca kolayca iş bulabileceğini ifade etmişlerdir. Suvacı ve Aydın (2016) çalışmasında da katılımcıların \%61,2'sinin kendilerini geliştirmede faydalı olacak meslekler seçtiklerini belirtmişlerdir. 
Mesleklerin yeterliliklerine yer verilen yetenek kategorisinde faktörlerin etki düzeyine bakıldığında \%50'nin altında bir sonuç yoktur. Bu ise öğrencilerin en az yarısının meslekler için gerekli olan yeteneklere sahip olduklarını düşündüğünü göstermektedir. İnsanlarla iyi bir iletişim kurabilme yeteneği iç mekân tasarımı mesleği için sahip olunması gereken önemli bir yetenektir ve öğrencilerin $\% 80,6$ 'sı bu yeteneğe sahip olduğunu düşünmektedir. Aynı şekilde katılımcılar insanlara hizmet etmeyi sevdiklerini $(\% 90,3)$, ikna yeteneğine sahip oldukların $(\% 63,9)$, planlama konusunda iyi olduklarını düşündüklerini $(\% 63,8)$ belirtmişlerdir. Tüm bu yetenekler bu meslek için olumlu sayılan yeteneklerdir. Suvacı ve Aydın (2016) çalışmasında katılımcıların mesleklerin yeterliliklerine yer verilen yetenek kategorisinde faktörlerin etki düzeyine bakıldığında; insanlarla iyi bir iletişim kurabilme yeteneğe sahip olduğunu (\%66,4), kendilerini iyi ifade edebildiğini $(\% 64,5)$, ikna yeteneğine sahip olduklarını $(\% 63,9)$, planlama konusunda iyi olduklarını $(\% 63,8)$, insanlara hizmet etmeyi sevdiklerini $(\% 58,6)$ ve diş görünüşlerinin insanları etkilediğini düşündüklerini (\%52) belirtmişlerdir.

Sonuç olarak, öğrenciler meslekleri tercih etmelerinde kendi isteklerinin yanında iş olanağı yüksek ve ideallerindeki meslek olması da etkili olmuştur. Bunun yanında öğrenciler bu mesleklerin iş avantajı olan ve kendi yeteneklerine uyan meslekler olduklarını düşünmektedir. Öğrenciler ayrıca bu mesleklerin kendilerini geliştirmelerine olanak tanıyan ve iş bulmada kolaylık sağlayan meslekler olduğunu da düşünmektedir. Başka üniversitelerde aynı mesleklerde öğrenim gören öğrencilere bu ölçek uygulanarak elde edilen sonuçlarla bir karşılaştırma yapılması önerilebilir.

\section{KAYNAKÇA}

Akar, C. (2012). Üniversite Seçimini Etkileyen Faktörler: İktisadi ve İdari Bilimler Üzerine Bir Çalışma, Eskişehir Osman Gazi Üniversitesi İktisadi ve İdari Bilimler Dergisi, 7 (1) :97-120.

Akbayır, K. (2002). Öğretmenlik Mesleğine Yönelmede Ailenin ve Branş Seçiminde Cinsiyetin Rolü, V. Ulusal Fen Bilimleri ve Matematik Eğitimi Kongresi Dergisi, 2: 1183-1188.

Alparslan, T. ve Kılcıgil, E. (2005). Beden Eğitimi ve Spor Yüksek Okulu Öğrencilerinin SosyoKültürel Yapı Meslek Seçimi İlişkisi, Ankara Üniversitesi Beden Eğitimi Spor Bilimleri Dergisi, 3 (1) : 17-26.

Alper, Z. ve Özdemir, H. (2004). Uludağ Üniversitesi Tıp Fakültesini Tercih Eden Öğrencilerin Kimi Sosyo-Demografik Özellikleri ve Mesleğe Bakış Açıları, Uludă̆ Üniversitesi Tıp Fakültesi Dergisi, 30 (2):93-96.

Altun, İ. (2000). Kocaeli Sağlık Yüksekokulu Öğrencilerinin Kişisel Değerleri ve Meslek Seçimlerine Etki Eden Faktörler, I. Uluslararası VIII. Ulusal Hemşirelik Kongresi Kitabı, Antalya, 75-82.

Anafarta, A. (2014). İstatistiki Uygulamalar Ders Notu. Akdeniz Üniversitesi, Turizm Fakültesi, Bilgisayar Laboratuvarı, Antalya.

Andsoy, I.I., Güngör, T. ve Bayburtluoğlu, T. (2012). Karabük Üniversitesi Sağlık Yüksekokulu Öğrencilerinin Hemşireliği Tercih Etme Nedenleri ve Mesleğin Geleceği İle İlgili Görüşleri, Balıkesir Sağlık Bilimleri Dergisi, 1:124-130. 
Aytekin, A. (2005). Meslek Seçimini Etkileyen Sosyo-Ekonomik ve Kültürel Faktörler: Isparta Örneği, Yüksek Lisans Tezi, Süleyman Demirel üniversitesi, Isparta.

Baharlı, G., Saraçoğlu, G.V. ve Bülbül A. (2013). Hemşirelik Öğrencilerinin Meslek Secimi Nedenleri ve Hemşirelik Mesleğini Sürdürmeye Yönelik Görüşleri ve Bunları Etkileyen Etmenler, 14.Ulusal Hemşirelik Kongresi, Bodrum/Muğla, 25-27- Ekim, 154.

Baltacı, F. ve Üngören, E. (2010). Turizm Eğitimi Alan Öğrencilerin Eğitim Memnuniyetlerinin ve Geleceğe Yönelik Bakış Açılarının Belirlenmesine Yönelik Bir Araştırma, 11. Ulusal Turizm Kongresi Bildiriler Kitabı, Detay Yayıncllık, Ankara.

Cernicova, M. and Palea, A. (2014). Measuring The Students Perception Chosen Profession Case Study: Pr Students in Western Romania, Procedia Social And Behavioral Sciences, 116: 2825-2831.

Ceylan, E., Cinser, B.B., Soytürk, S., Şengün, T. ve Erbay, H. (2017). Bir Tip Fakültesi Öğrencilerinin Meslek Tercihinde Etkili Olan Faktörler, Jourrnal of Medical Education and Informatics, 1:2-12.

Cullen, B. J., Jacob, A.B. and Levitt S.D. (2005). The İmpact Of Scholl Choice On Student Outcomes An Analysis Of The Chicago Public School, Journal Of Public Economics, 89: 729-860.

Çelik, N. ve Üzmez, U. (2014). Üniversite Öğrencilerinin Meslek Seçimini Etkileyen Faktörlerin Değerlendirilmesi: Çağrı Merkezi Hizmetler Örneği, Elektronik Mesleki Gelişim ve Araştırma Dergisi, 2(19): 94-105.

Çiftçi, G.E., Bülbül, S.F., Muluk, N.B., Duyan, G.Ç. ve Yılmaz, A. (2011). Sağlık Bilimleri Fakültesini Tercih Eden Öğrencilerin, Üniversite ve Meslek Tercihlerinde Etkili Olan Faktörler (Kırıkkale Üniversitesi Örneği), J Kartal TR, 22:151-160.

Demagalhaes, R., Wilde, H. and Fitzgerald, L.R. (2011). Factors Affecting Accounting Students Employment Choices: A Comparison Of Students And Practitioners Views, Journal Of Higher Education Theory And Practice, 11(2): 32-40.

Deniz, M.G. (2015). Bilgisayar ve Öğretim Teknolojileri Eğitimi Bölümünde Öğrenim Gören Öğrencilerin Bölümlerini Seçme Nedenlerinin İncelenmesi: Trakya Üniversitesi Örneği, Trakya Üniversitesi sosyal Bilimler Dergisi, 17(2):297-311.

Deniz, S. (2001). Bireyin Meslek Seçimini Etkileyen Kaynaklar: Yeni Teknolojilerden İnternet, Muğla Üniversitesi SBE Dergisi, 6: 1-9.

Dinç, E. (2008). Meslek Seçiminde Etkili Faktörlerin İncelenmesi: Meslek Yüksek OkuluMuhasebe Programı Öğrencileri Üzerine Bir Araştırma, Kocaeli Üniversitesi Sosyal Bilimler Enstitüsü Dergisi, 16(2): 90-106.

Dinç, S., Kaya, O. ve Şimşek, Z. (2007). Harran Üniversitesi Sağlık Yüksekokulu Öğrencilerinin Hemşirelik Mesleği Hakkındaki Bilgi, Düşünce ve Beklentileri, Atatürk Üniversitesi Hemşirelik Yüksekokulu Dergisi, 10(1):1-9.

Dündar, A.N. ve Özdemir, E. (2015). Öğrencilerin Gıda Teknolojisi ve Makine Programlarını Tercih Etme Nedenleri ve Kariyer Planları, 4th International Vocational Schools Symposium, Yalova Üniversitesi, 232-237. 
Erdem B. ve Kayran M.F. (2013). Balıkesir Üniversitesi Turizm İşletmeciliği ve Otelcilik Yüksekokulu Öğrencilerinin Meslek Seçimini Etkileyen Faktörler Üzerine Bir Araştırma, Cumhuriyet Üniversitesi İktisadi ve İdari Bilimler Dergisi, 14(1):81-106.

Erdinç, S.B.ve Kahraman, S. (2012). Turizm Mesleğini Seçme Nedenlerinin İncelenmesi, VI. Lisansüstü Turizm Öğrencileri Araştırma Kongresi, Kemer, Antalya, 229-237.

Erdoğan, S., Şanll, H.S. ve Bekir, H.S. (2005). Gazi Üniversitesi, Eğitim Fakültesi Öğrencilerinin Üniversite Yaşamına Uyum Durumları. Kastamonu Ĕ̆itim Dergisi, 13(2), 479-496.

Erkal, S., Yalçın, A.S. ve Sancar, B. (2012). Ankara Üniversitesi Sağlık Bilimler Fakültesi Öğrencilerinin Ebelik ve Hemşirelik Bölümlerini Seçme Nedenleri, Ankara Să̆llk Bilimler Dergisi, 1(1):73-90

Erol, A.Y. ve M, H.M (2012). Üniversite Öğrencilerinin Üniversite Tercihlerinin Belirleyicileri: Hakkâri Örneği, Sosyal ve Beşeri Bilimler Dergisi, 4(2): 1-10.

Eşer, İ., Khorshid, L. Denat, Y. (2008). Hemşirelik Mesleğini Algılamada İlk Klinik Uygulamanın Etkisi, Ege Üniversitesi Hemşirelik Yüksekokulu Dergisi, 24(1):15-26.

Fuller, A.M. ve Delorey, R. (2016). Making The Choice: University and Program Selection Factors For Undergraduate Management Education In Maritime Canada, The International Journal of Management Education, 14:176-186.

Genç, G., Kaya, A. ve Genç, M. (2007). İnönü Üniversitesi Tıp Fakültesi Öğrencilerinin Meslek Seçimini Etkileyen Faktörler, İnönü Üniversitesi Eğitim Fakültesi Dergisi, 8 (14): 49-63.

Green, P.C., Navarro-Paniagua, M., Ximenez-De-Embun, D. ve Mancebon, M.J. (2014). School Choice and Student Wellbeing, Economics of Education Review, 38:139-150.

Güllüce, A. Ç. ve Kaygın, E. (2013). Çalışanların Demografik Değişkenleri Açısından Tükenmişlik Düzeylerini Belirlemeye Yönelik Bir Araştırma. Atatürk Üniversitesi İktisadi ve İdari Bilimler Dergisi, 27(2):235-252.

Gündoğan, A. (2016). Öğrencilerin Üniversite Tercihlerini Etkileyen Faktörler: Ortaca Örneği, Uluslararası Sosyal Araştırmalar Dergisi, 9(42):1238-1246.

Hacıömeroğlu, G. ve Taşkın, Ç.Ş. (2010). Fen Bilgisi Öğretmenliği Ve Ortaöğretim Fen ve Matematik Alanları (Ofma) Eğitimi Bölümü Öğretmen Adaylarının Öğretmenlik Mesleğine İlişkin Tutumları, Ahi Evran Üniversitesi Eğitim Fakültesi Dergisi, 11(1); 77-90.

Hamamcı, Z. ve Hamurlu, M.K. (2005). Anne Babaların Meslek Gelişimine Yardımcı Olmaya Yönelik Tutumları ve Bilgi Düzeylerinin Çocukların Mesleki Kararsızlıkları İle İlişkisi, İnönü Üniversitesi Eğitim Fakültesi Dergisi, 6(10): 55-69.

İnce, S. ve Khorshid, L. (2015). Hemşirelik Öğrencilerinin Meslek Seçimini Etkileyen Faktörlerin Belirlenmesi, Anadolu Hemşirelik ve Sağlık Bilimleri Dergisi, 18(3):163-171.

Jonston, J., Mckeown, E. ve Mcewen, A. (1999). Choosing Primary Teaching: The Perspectives Of Males And Females İn Training, Journal of Educating For Teaching, 25(1): 55-64.

Kıyak, S. (2006). Genel Lise Öğrencilerinin Meslek Seçimi Yaparken Temel Aldığı Kriterler, (Yayınlanmamış Yüksek Lisans Tezi), Yeditepe Üniversitesi Sosyal Bilimler Enstitüsü, İstanbul. 
Kızğut, S. ve Ergöl, Ş. (2011). Sağlık Yüksekokulu Öğrencilerinin Hemşireliği Algılayışı Hemşirelik Rollerine ve Hemşireliğin Geleceğine Bakışı, Anadolu Hemşirelik ve Sağlık Bilimleri Dergisi, 14(2), 10-15.

Koç, Z. ve Sağlam, Z. (2009). Lise Son Sınıf Öğrencileirinin Hemşirelik Mesleğine İlişkin Görüşleri ve Mesleği Seçme Durumlarının Belirlenmesi, Atatürk Üniversitesi Hemşirelik Yüksekokulu Dergisi, 12(3):1-11.

Korkut-Owen, F. (2008). Mesleki Seçimleri Etkileyen Ana Etmenler, (R. Özyürek Ed). Kariyer Yolculuğ u, Ankara: Ulusal Ajans.

Korkut-Owen, F., Kepir, D.D., Özdemir, S., Ulaş, Ö. ve Yılmaz, O. (2012). Üniversite Öğrencilerinin Bölüm Seçme Nedenleri, Mersin Üniversitesi Ĕ̆itim Fakültesi Dergisi, 8(3): 135-151.

Mccabe, R., Nowak, M. ve Mullen, S. (2005). Nursing Careers: What Motivated Nurses To Choose Their Profession, Australian Bulletin of Labour, 31(4): 384-406.

Mızrak, Ş. ve Şenel, E. (2011). Meslek Liselerinde Tekstil Konfeksiyon Programının Seçimini Etkileyen Faktörler ve Programa Talep Oranı (Konya, Karaman Ve Aksaray İlleri Örneği), Selçuk Üniversitesi Sosyal Bilimler Enstitüsü Dergisi, 25:183-201.

Özpancar, N., Aydın, N. ve Akansel, N. (2008) Hemşirelik 1. Sınıf Öğrencilerinin Hemşirelik Mesleği İle İlgili Görüşlerinin Belirlenmesi, Cumhuriyet Üniversitesi Hemşirelik Yüksekokulu Dergisi, 12:9-17.

Özsoy, G., Özsoy, S., Özkara, Y. ve Memiş, A.D. (2010). Öğretmen Adaylarının Öğretmenlik Mesleğini Tercih Etmelerinde Etkili Olan Faktörler, Ilköğretim Online, 9(3): 910-921, http://ilkogretim-online.org.tr.

Özveren, H., Gülnar, E. ve Özden, D. (2017). Hemşirelik Öğrencilerinin Meslek Seçimini Etkileyen Faktörlerin Belirlenmesi, Turkish Journal of Clinics and Laboratory, 8(2):57-64.

Özyürek, R. ve Atıcı, M. (2002). Üniversite Öğrencilerinin Meslek Seçimi Kararında Kendilerine Yardım Eden Kaynakların Belirlenmesi, Türk Psikolojik Danışma ve Rehberlik Dergisi, 2(17):33-42.

Paulick, I., Retelsdorf, J. ve Möller, J. (2013). Motivation For Choosing Teacher Education: Associations With Teachers Achievement Goals And İnstructional Practices, International Journal of Educational Research, 61: 60-70.

Pekkaya, M. ve Çolak, N. (2013). Üniversite Öğrencilerinin Meslek Seçimini Etkileyen Faktörlerin Önem Derecelerinin AHP İle Belirlenmesi, International Journal of Social Science, 6(2): 797-818.

Saatc1, G. (2013). Öğrencilerin Pazarlama Mesleğini Seçeme Nedenlerinin İncelenmesi: Harmancık Meslek Yüksekokulu Örneği, Uşak Üniversitesi Sosyal Bilimler Dergisi, 6(3):36-50.

Sarıkaya, T. ve Khorshid, L. (2009). Üniversite Öğrencilerinin Meslek Seçimini Etkileyen Etmenlerin İncelenmesi: Üniversite Öğrencilerinin Meslek Seçimi, Türk Ĕgitim Bilimleri Dergisi, 7(2): 393-423.

Sathapornvajana, S. ve Watanapa, B. (2012). Factors Affecting Students Intention To Choose It Program, Procedia Computer Science, 13: 60-67. 
Sertel, E., Yıldırım, H. ve Akyol, S.Ö. (2017). Meslek Yüksekokulu Öğrencilerinin Okul Tercih Sebepleri ve Uyum Durumları: Sivrihisar Örneği, Mehmet Akif Ersoy Üniversitesi Sosyal Bilimler Enstitüsü Dergisi, 9(21):101-117

Sipahi, B., Yurtkoru, E.S., ve Çinko, M. (2010). Sosyal Bilimlerde SPSS'le Veri Analizi, 3. Baskı, İstanbul, Beta Yayıncilık.

Suvacı, B. ve Aydın, D. (2016). Ön Lisans Öğrencilerinin Meslek Seçimini Etkileyen Faktörlerin Belirlenmesi: Büro Yönetimi ve Yönetici Asistanlı̆̆ı ve Pazarlama Bölümü Öğrencileri Örneği, III. Ulusal Meslek Yüksekokulları Sosyal Ve Teknik Bilimler Kongresi, Aydın.

Sverko, I. ve Babaroviç, T. (2016). Integrating Personality And Career Adaptability Into Vocational İnterest Space, Journal of Vocatioanl Behavior, 94: 89-103.

Şahin-Ören, T. (2017). Web Tabanlı Pazarlama Yapan Seyahat Acentalarının Pazarlama Faaliyetlerinin Etik Açıdan Değerlendirilmesi, İstanbul Journal of Sciences, 15:2147-3490.

Şengün, Gökhan. (2013). Lise Öğrencilerinin Alan Seçimini Etkileyen Faktörlerin İncelenmesi, Yayımlanmamış Yüksek Lisans Tezi, Ankara Üniversitesi Eğitim Bilimleri Enstitüsü, Ankara.

Şirin, A., Öztürk, R. Bezci., G. Çakar ve Çoban, A. (2008). Hemşirelik Öğrencilerinin Meslek Seçimi ve Mesleği Uygulamaya Yönelik Görüşleri, Dirim Tıp Gazetesi, 83: 69-75.

Tamayose, T.S., Madjidi, F., Schmieder-Ramirez, J. ve Rice, G.T. (2004). Important Factors When Choosing A Career In Public Health, Californian Journal of Health Promotion, 2(1): 65-73.

Taş, M.Y. (2012). Demirci Eğitim Fakültesi Sosyal Bilgiler Öğretmenliği Adaylarının Profili ve Sosyal Bilgiler Öğretmenliğini Tercih Etme Nedenlerinin Değerlendirilmesi, Celal Bayar Üniversitesi Sosyal Bilimler Dergisi, 10(2):64-76.

Tataroğlu, B., Özgen, K. ve Alkan, H. (2011). Matematik Öğretmen Adaylarının Öğretmenliği Tercih Nedenleri ve Beklentileri, 2nd International Conference On New Trends in Education And Their Implications, Ankara: Siyasal Kitabevi.

Tunç, G., Akansel, A. ve Özdemir A. (2007). Hemşirelik ve Sağllk Memurluğu Öğrencilerinin Meslek Seçimini Etkileyen Faktörler, Maltepe Üniversitesi Hemşirelik Bilim ve Sanatı Dergisi, 3(1):24-31.

Tüfekçi, F. ve Yıldız, A. (2009). Öğrencilerin Hemşireliği Tercih Etme Gerekçeleri ve Gelecekleri İle İlgili Görüşleri, Atatürk Üniversitesi Hemşirelik Yüksekokulu Dergisi, 12(1): 31-37.

Udoh, N.A. ve Sanni, K.B. (2012). Parental Back Ground Variables And The Career Choice Of Secondary Schools Tudents In Uyolocal Goverment Area Nigeria. Mediterranean Journal Of Social Sciences, 3(1):497-504.

Ulaş, Ö. ve Yıldırım, İ. (2015). Lise Öğrencilerinde Meslek Olgunluğun Yordayıcıları, Hacettepe Üniversitesi Eğitim Fakültesi Dergisi (H.U. Journal of Education), 30(2), 151-165.

Ulaş, Ö., Zorbaz-Demirtaş, S., Dinçel, E.F., Kınay-Çiftfiliz, G. ve Çoştur, R. (2017). Özel Okulda Öğrenim Görmekte Olan Lise Öğrencilerinin Meslek Seçimini Etkileyen Faktörler, Abant İzzet Baysal Üniversitesi Eğitim Fakültesi Dergisi, 17(1):441-456.

URL1, (2018). http://www.edufixx.com/spss/guvenilirlik-analizireliability-analysis-nedir-nasilyapilir/ 
Uyguç, N. (2003). Cinsiyet, Bireysel Değerler ve Meslek Seçimi, Dokuz Eylül Üniversitesi İktisadi ve İdari Bilimler Dergisi, 18(1): 93-103.

Ünal, S., Gürhan, N., Saral, E. ve Özbaş, A.A. (2008). Hemşirelik Öğrencilerinin Sosyodemografik Özellikleri ve Hemşirelik Mesleğini Seçme Nedenleri, İstanbul Üniversitesi Florence Nightingale Hemşirelik Dergisi, 16(63): 179-187.

Ünlü, S., Özgür, G.L. ve Gümüş, B.A. (2008). Hemşirelik Yüksekokulundaki Öğrencilerin Hemşirelik Mesleği ve Eğitimi İle İlgili Görüş ve Beklentileri, Ege Üniversitesi Hemşirelik Yüksekokulu Dergisi, 24(1):43-56.

Watt, H.M.G., Richardson, P. W., Klusmann, U., Kunter, M., Beyer, B. ve Trautwein, U. (2012). Motivations For Choosing Teaching As A Career: An İnternational Comparison Using The Fit-Choice Scale, Teaching And Teacher Education, 28: 791-805.

Yanıkkerem, E., Altınparmak, S. ve Karadeniz, G. (2004). Gençlerin Meslek Seçimini Etkileyen Faktörler ve Benlik Saygilar1, Nursing Forum Dergisi, 7(2): 61-62.

Yelken, K. (2008). Ortaöğretim Son Sınıf Öğrencilerinin Üniversite Tercihlerini ve Meslek Seçimini Etkileyen Faktörler: Sakarya İl Merkezi Örneği, (Yayınlanmamış Yüksek Lisans Tezi), Sakarya Üniversitesi Sosyal Bilimler Enstitüsü, Sakarya.

Yılmaz, V. İmren, B., Ünsal, A.,ve Demir, G. (2011). Hemşirelik Öğrencilerinin Meslek Seçimine Yönelik Görüşleri, 10. Uluslararası Katılımlı Hemşirelik Öğrencileri Kongresi Bildiri Kitabı, Gaziantep, 104.

Yolcu, H. (2011). Kız Meslek Liselerine Olan Bireysel Eğitim İstemini Etkileyen Etkenler: Kastamonu İli Örneği, Kuram ve Uygulamada Eğitim Yönetimi, 17(3):453-483.

Yücel, Ş.Ç., Güler, E.K., Eşer, İ., ve Khorshid, L. (2011). İki Faklı Eğitim Sistemi İle Öğrenim Gören Hemşirelik Son Sınıf Öğrencilerinin Hemşirelik Mesleğini Algılama Durumlarının Karşılaştırılması, Ege Üniversitesi Hemşirelik Yüksekokulu Dergisi, 27(3):1-8. 